\title{
State of a sustainable drainage system at end-of-life: assessment of potential water pollution by leached metals from recycled pervious pavement materials when used as secondary aggregate
}

\author{
Mbanaso, F., Charlesworth, S., Coupe, S., Newman, A. \& \\ Nnadi, E. $O$.
}

Author post-print (accepted) deposited by Coventry University's Repository

Original citation \& hyperlink:

Mbanaso, F, Charlesworth, S, Coupe, S, Newman, A \& Nnadi, EO 2020, 'State of a sustainable drainage system at end-of-life: assessment of potential water pollution by leached metals from recycled pervious pavement materials when used as secondary aggregate', Environmental Science and Pollution Research, vol. 27, no. 5, pp. 4630-4639. https://doi.org/10.1007/s11356-019-06480-5

$\begin{array}{ll}\text { DOI } & 10.1007 / \mathrm{s} 11356-019-06480-5 \\ \text { ISSN } & 0944-1344 \\ \text { ESSN } & 1614-7499\end{array}$

Publisher: Springer

The final publication is available at Springer via http://dx.doi.org/10.1007/s11356-01906480-5

Copyright $(C$ and Moral Rights are retained by the author(s) and/ or other copyright owners. A copy can be downloaded for personal non-commercial research or study, without prior permission or charge. This item cannot be reproduced or quoted extensively from without first obtaining permission in writing from the copyright holder(s). The content must not be changed in any way or sold commercially in any format or medium without the formal permission of the copyright holders.

This document is the author's post-print version, incorporating any revisions agreed during the peer-review process. Some differences between the published version and this version may remain and you are advised to consult the published version if you wish to cite from it. 


\title{
State of a Sustainable Drainage System at end-of-life: Assessment of Potential Water Pollution by Leached Metals from Recycled Pervious Pavement Materials when used as Secondary Aggregate
}

\author{
Fredrick U. Mbanaso*1, Susanne M. Charlesworth ${ }^{1}$, Stephen J. Coupe ${ }^{1}$, Alan P. \\ Newman ${ }^{2}$ and Ernest O. Nnadi ${ }^{1}$ \\ ${ }^{1}$ Centre for Agroecology, Water and Resilience (CAWR), Coventry University, Coventry, UK \\ ${ }^{2}$ Centre for the Built and Natural Environment Research, Coventry University, Coventry, UK \\ *Corresponding author e-mail: mbanasof@uni.coventry.ac.uk
}

\section{ABSTRACT}

Sustainable Drainage systems (SuDS) have emerged as an effective and attractive approach for stormwater management, prevention of water pollution and flood control due to its sustainable, environmentally friendly and cost-effective approaches. One of the SuDS devices widely used to infiltrate, store and treat surface runoff which allows it to recharge groundwater is the pervious paving systems (PPS). Previous studies have demonstrated relatively high pollution removal efficiencies typically ranging from $98.7 \%$ for total hydrocarbons to $89 \%$ of COD. Though a small number of the researches have assessed the performance characteristics of the PPS system in long established installations in terms of retention of pollutants, hydrological features, biodegradation of pollutants etc., none has assessed the risk of potential groundwater and soil pollution by pollutants such as metals retained in the PPS materials either as a disposed waste material (in the case of used geotextiles) or during re-use as secondary aggregates. Thus, this study evaluated potential risks associated with the decommissioning and beneficial use of wastes produced during the disassembly of a PPS. The authors believe that this was the first PPS to be addressed in this way. The method involved the determination of leachable concentrations of 14 metals in the PPS samples made up of extracts from the model profile which included the Geotextile fibre (G), Dust alone (D), Aggregates and Dust (AD), Aggregates Alone (AA), and Pavement blocks (P) which were analysed and compared to two different groups of regulatory threshold limits. The results showed that the measured concentrations of all the metals were below the appropriate threshold values for irrigation purposes as specified by FAO and USEPA. Furthermore, results all indicated that the dismantled materials can be were all below EU LFD WAC limits for inert waste indicating relative ease of disposal 
and suitability for use as recycled aggregate. This, admittedly limited data, indicates that recycling of aggregates from demolition wastes arising from end of life PPS would not be limited by the potential leaching of heavy metals, including re-use within another PPS. This would minimize dependence on virgin aggregates and hence, reduce rate of exploitation of natural resources and improve sustainability score card of SuDS.

Keywords: Water pollution; Pervious Pavement System; Sustainable Drainage System; Metals; Waste Control Management; Leaching; Aggregates Recycling

\section{INTRODUCTION}

There is no doubt that increasing global urban development, population and climate change will continue to exert more pressure on the built environment. By 2050, it is estimated that $70 \%$ of global population of 9.8 billion will live in cities, up from current $49 \%$ today (UN 2018). This entails massive additional infrastructural development to cope with this influx. In order to ensure an ecologically sustainable development to cater for the growing building and infrastructural needs, sustainable construction has become one of the major considerations for building professionals globally. Currently, there is a growing emphasis on the re-modelling of urban spaces to help revitalise the City Centres (Department for Communities and Local Government 2012) and also to reduce impact of flash flooding due to unpredictable and extreme weather conditions which, climate scientists have predicted will worsen with time (IPCC 2013). Apart from city centres, residential areas are also trending similarly with reduction of front gardens, which is valuable for surface water control (Kelly, 2016). For example, a quarter of London's front gardens have been paved over mainly for off-road vehicular parking (RHS 2015; Greater London Authority (2016). Similarly, there was a $13 \%$ increase in the development of paved surfaces on 
front gardens in a sub-urban area of Leeds as a result of urban creep (Perry and Nawaz 2008). Also, increased rate of urban creep was reported in Scotland (Wright et al. 2011). In 2011, the number of houses which converted front gardens into paved surfaces for car parking almost doubled in the past 20 years, from just $16 \%$ of houses in 1991 to 30\% in 2011 (RAC Foundation 2012). Since planning controls are increasingly demanding surfaces paved so as to be permeable, these cities are increasingly depending largely on urban landscape of which pavement structures are important components as sustainable urban drainage devices (Newman et al. 2011; Nnadi et al. 2015) and an embodiment of urban culture (Zhou et al. 2015). These pavement structures are Low Impact Development (LID) features designed to mimic the predevelopment hydrology of a milieu by using design techniques which detain, infiltrate, treat, store, and evaporate runoff at source (LID Centre 2007). LIDs, also known as Sustainable Drainage systems (SuDS), have emerged as an effective and attractive approach for storms (at least up to the pavement's design limits), pollution retention and biodegradation, water quality improvement and groundwater recharge.

One of the SuDS devices increasingly used to infiltrate, store and treat surface runoff which could allow groundwater recharge (if designed to infiltrate stormwater directly into soil) is the pervious paving systems (PPS). Due to its multi-benefit attributes, PPS has been used in different applications such as, rainwater recycling with ground source heat pump (GSHP) technology for improved environmental performance of new domestic building developments (Sañudo-Fontaneda et al. 2017), tanked sub-base storage system for rainwater harvesting (Das and Saikia 
2018), mitigation of urban heat island effect (Liu et al 2018) and avoidance of elevation of temperature of receiving water bodies (USGS 2018) etc.

The structure of PPS has also been shown to possess the capacity for the retention and biodegradation of urban pollutants which improve discharge water quality. They include the removal efficiency of $98.7 \%$ of total hydrocarbons (Bond 1999), $95 \%$ of suspended solids (Hogland et al. 1987), 89\% of COD and 93\% of lead (Baladès et al. 1992 ) etc. In a study to evaluate the effects of a porous pavement with reservoir structure on the quality of runoff water and soil, Legret et al. (1996) observed a reduction in the concentrations of lead, zinc and cadmium by $79 \%, 72 \%$ and $67 \%$ respectively; demonstrating the effects of the pavement's reservoir on the runoff waters in terms of decrease in pollutants concentrations. Dierkes et al. (2002) studied the pollution retention capacity of different permeable materials in both laboratory and field conditions and, documented that $89-98 \% \mathrm{~Pb}, 74-98 \% \mathrm{Cd}$, 89$96 \%$ and $72-97 \% \mathrm{Zn}$ were removed by the systems; the authors were of the opinion that basalt and gravel as subbase materials are better in removing heavy metals than limestone and sandstone materials. Recently, Sounthararajah et al. (2017) investigated the removal of heavy metals using permeable pavement system with a titanate nano-fibrous adsorbent column as a post treatment in Australia and, found that the PPS removed $41-72 \%, 67-74 \%, 38-43 \%, 61-72 \%, 63-73 \%$ of $\mathrm{Cd}, \mathrm{Cu}, \mathrm{Ni}, \mathrm{Pb}$, and $\mathrm{Zn}$, respectively; the same study suggested that there is higher nano-adsorbent adsorption capacities for heavy metals than bedding materials. Metals are naturally occurring elements widely distributed in the environment due to their multiple applications in different sectors such as industrial, medical, agricultural and 
domestic. Their toxicity is a function of numerous factors such as the dose factor, age, genetics, chemical species, route of exposure and nutritional status of those exposed to them (Jaishankar et al. 2014). Due to their high level of toxicity, metals such as mercury, lead, arsenic, cadmium and chromium are regarded as systemic toxicants that can cause organ damage even at low concentration levels and therefore, are of environmental and health concern. Some of them such as arsenic, lead, mercury, cadmium etc. have been classified by the US Agency for Toxic Substances and Disease Registry (ATSDR) as priority pollutants due to their toxicity (ATSDR 2017).

However, when a PPS structure is installed, it is also subject to routine maintenance to ensure its functionality. While some studies have shown that the PPS systems can operate effectively and adequately with no maintenance regime for periods of 10 to 20 years in the UK (Wild et al. 2002; Schlüter and Jefferies 2001; Pratt 2004; INTERPAVE 2008; INTERPAVE 2006; Imbe et al. 2002), others reported 10 to 20 years in Australia (Shackel 2010) and over 20 years in the US (Smith 2019). Studies have assessed the performance characteristics of the PPS system at end-of-life such as the retention of pollutants (Mbanaso et al. 2013; Dierkes et al. 2002); hydrological features (Braswell et al. 2018; Sañudo-Fontaneda et al. 2018); biodegradation of pollutants (Imran et al. 2013; Newman et al. 2014) etc., none has evaluated the risk of potential groundwater pollution (by leached metals from recycled pervious pavement materials when used as secondary aggregate) and soil pollution by pollutants such as metals retained in the PPS. Furthermore, as a SuDS device, there is the need to reappraise the wastes generated at end-of-life during dismantling for 
potential beneficial use for sustainability. In the present context, the term "end-oflife", refers to the phase in the lifecycle of the installation when the PPS was dismantled after being previously in service. Thus, the aim of this study was to evaluate potential risks associated with PPS during decommissioning and the beneficial use of wastes generated during dismantling of the PPS.

\section{METHODS}

This study which was conducted on an 11-year old parking lot constructed as a research assessment bed in the north west region of England. The details of the dimensions are as previously described (Newman et al. 2014) as shown in Figure 1 while, the schematic cross section is as shown in Figure 2:

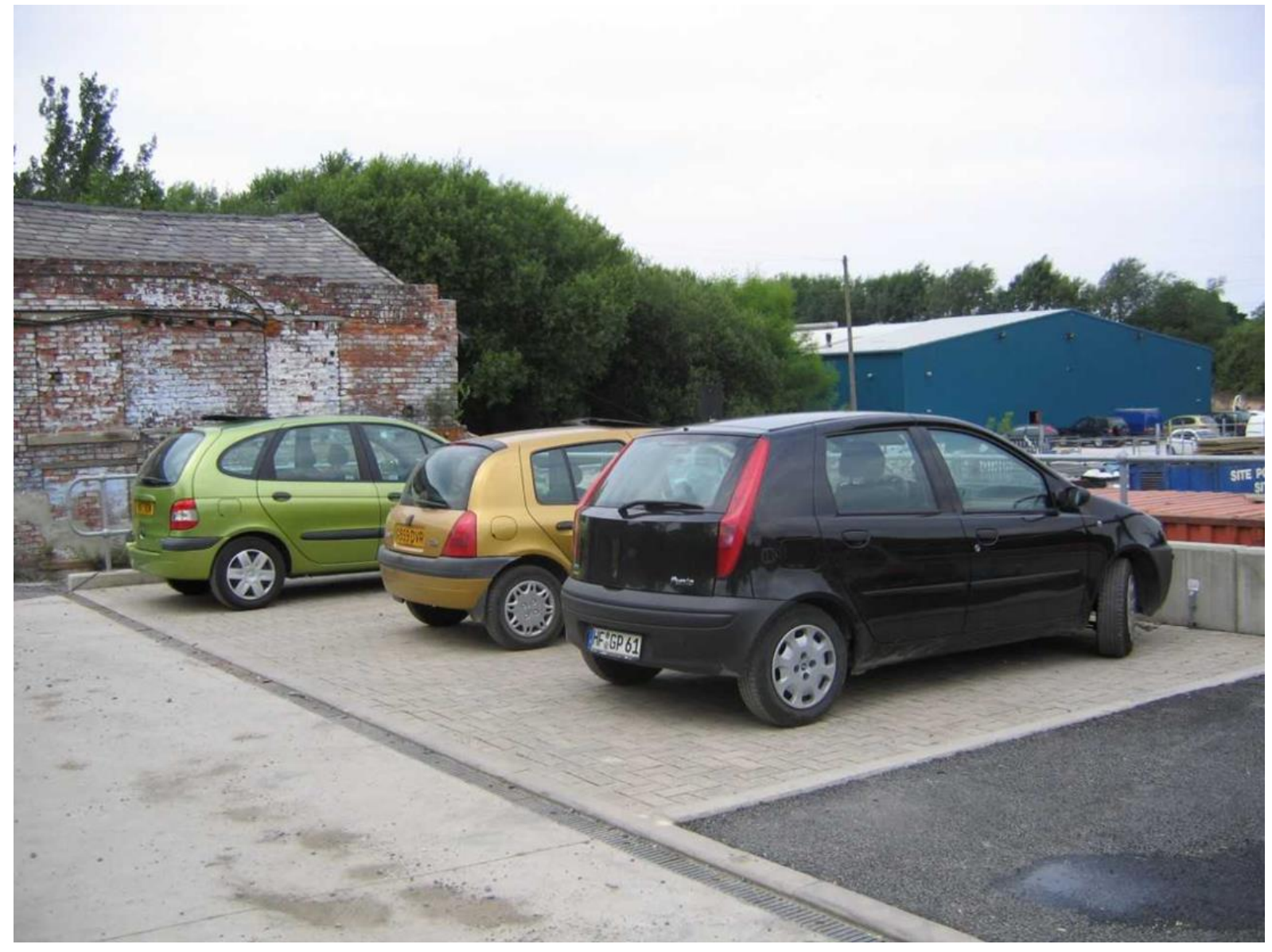

Figure 1: A snapshot of the study site 


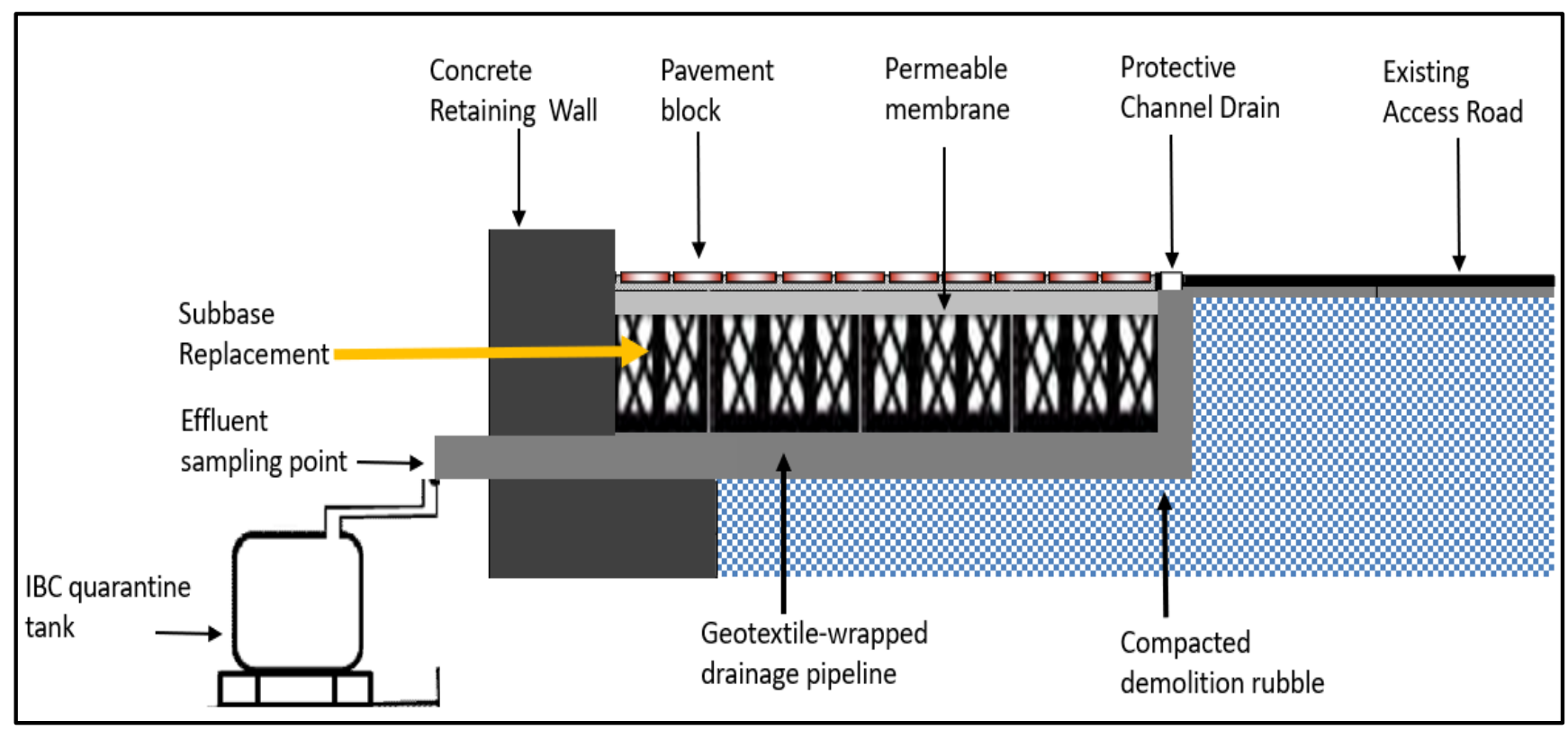

Figure 2: A cross sectional view of the PPS model comprising of the pavement blocks (P), supporting bedding layer made up of aggregates profiled as aggregates alone (AA) beneath $P$, the mid-section as aggregates \& dust (AD) while, Dust alone (D) was the lower section. The structure also had a drainage system wrapped with a geotextile fabric (G).

This parking lot was used for both staff parking and parking of plant and trucks for 11 years and thus, one can reasonably expect pollutant loadings to have been reasonably typical. However, this was the first time such a study has been carried out and whilst the conclusions reached here can be seen as a good guide to the environmental impact of re-use of PPS aggregates, further studies on parking areas with different uses will be justified.

Some indication of the effluent output prior to decommissioning can be seen in Newman et al. (2015a). Data generated from studies carried out using the test bed and published outputs are available (Newman et al. 2015b; Newman et al. 2014). The results from these papers indicate that when the PPS is in normal use, such as a parking facility, pollutant release from the system which had been subjected to high 
loading events even after ten years, is minimal. Most of the hydrocarbons applied to the system were retained within the structure or biodegraded.

\subsection{Dismantling of Test Bed and collection of samples}

As earlier noted, 'end-of-life' of a SuDS device could be referred to as the end of the functionality of a PPS to treat pollutants due to clogging or when it is dismantled for refurbishing. In the present study, end-of-life assessment was necessitated by the need to collect as much data from the installation as possible due to decommissioning as a result of relocation and, not because of clogging or refurbishment. When the test bed was dismantled, it was assessed to determine the distribution pattern of the contaminants as well as their concentrations within the system. Using a piece of spatula, individual pieces of the PPS made of the pavement blocks, aggregates and the geotextile fabric were cautiously transferred into labelled storage bags and stored at low temperature of about $4^{\circ} \mathrm{C}$ while being shipped to the laboratory for analysis. The model sampling which was done in tiered order included samples from the pavement blocks ( $P$ ), Aggregates Alone (AA), Aggregates and Dust $(A D)$, Dust alone (D) and polypropylene Geotextile fabric (G). The sampling amount was about $250 \mathrm{~g}$ of geotextile fabric and, $2.5 \mathrm{~kg}$ each of $\mathrm{P}, \mathrm{AA}, \mathrm{AD}, \mathrm{D}$.

\subsection{Methods of Analysis}


The samples were delivered to an analytical laboratory accredited by the United Kingdom Accreditation Service (UKAS) to ISO/IEC 17025 standard for analysis. ALS laboratory is also certified to Environment Agency of England \& Wales Monitoring Certification Scheme (MCERTS), and the Drinking Water Inspectorates' Drinking Water Testing Specification (DWTS). Details of the analytical protocols are as follows.

\subsubsection{Metals}

The concentrations of 14 metals in the PPS samples made up of $P, A A, A D, D$ and $G$, were analysed via inductively coupled plasma (ICP) spectroscopy and then compared to appropriate risk-based regulatory threshold limits. The regulatory threshold limits included the Food and Agriculture Organization (FAO) Wastewater quality guidelines for agricultural use and, US EPA Guidelines for Water Reuse: Recommended water quality criteria for irrigation. It was thought that if these metals leach onto adjoining farmlands during decommissioning, they may be taken up by plants including food crops during agricultural activities and may eventually be found in the food chain, thus, may pose a health issue.

Preparation of the test samples was based on method BSEN 12457.3. Before the commencement of the analysis, a blank standard was used to dilute a fraction of the sample by 20 -fold. The samples were then passed through the inductively coupled plasma (ICP) spectroscope for the determination of the concentration of the metals. 


\subsubsection{Analysis of Leachate}

The leachable amounts of the metals were determined based on BSEN 12457-3:2000 and then compared with regulatory threshold limits used by some EU Member States for the control of pollution from aggregates to ensure that infiltrated leachates do not contaminate groundwater resources. Some EU Member States such as Austria, Czech Republic and France, rely fully or partly on the EU Landfill Directive (LFD) Waste Acceptance Criteria (WAC) for inert waste as the basis for their leaching criteria for use of waste aggregates (EU 2014). These also have associated financial consequence thus, it is necessary to carry out the assessment. The process is as follows:

Suspended and soluble analytes are percolated from the waste sample into water. This process is a two-stage batch test in accordance with the British standard, BSEN 12457-3:2000, at a liquid to solid ratios of 8 litres per kilogram and 2 litres per kilogram. Under defined conditions, the sample material, whose particle size was below $4 \mathrm{~mm}$, was brought into contact with water. After separation of the solid residue by filtration, the resultant leachate was assessed for $\mathrm{pH}$, conductivity and temperature to quantify leachate conditions.

Contaminants released from the solid could be due to the movement of a fluid which passes through the solid mass and, in the process, extracts suspended or soluble solids or mobilises the pollutants into the fluid stream. In the current context, it was thought that these wastes could infiltrate onto susceptible sites such as water bodies, adjoining farmlands or other sensitive systems. Consequently, if a farmer irrigates a farmland with leachate-containing water, there may be associated health 
issues from exposure, for instance, through breathing of air-borne contaminants during spraying. In this present study, data generated were assessed by evaluating against limits set for irrigation water on the supposition that if results obtained are acceptable for irrigating systems, then possibility of health issues due to heavy metals to exposed workers in terms of exposure through droplet inhalation or skin contact is acceptably low. However, further studies with respect to microbiology may be worthwhile. In a related study, Nnadi (2009) carried out an investigation of the biological water safety of recycled effluent from a PPS. Although the author acknowledged that the risks associated with microbial pollution of stormwater are normally considered to be higher than that from chemicals (Hamilton et al. 2005), same study demonstrated that PPS is effective in the removal of potential pathogenic pollutants such as A.polyphaga and E.coli and thus, offers greater opportunities for its use as water storage and recycling device.

\section{RESULTS \& DISCUSSION}

\subsection{Metals}

As can be seen from Table 1, the concentration of Cadmium (Cd) in all the PPS profiles was $<0.0001 \mathrm{mg} \mathrm{L}^{-1}$ (limit of detection). Given that, as previously mentioned, others have shown (Bond, 1999; Nnadi, 2009; Mbanaso et al. 2013) that Cd is efficiently retained within a PPS, this indicates that either the $\mathrm{Cd}$ was evenly distributed within the PPS system without any preferential deposition in any area of the structure or the Cd input to the system was insufficient, in this case, to cause a detectable accumulation. $\mathrm{Cd}$ is a non-nutritive metal which is naturally occurring in 
soils and can also be introduced into the environment through anthropogenic activities such as combustion of fossil fuel, mining and smelting of zinc-bearing or copper ores, incineration of waste etc. (ATSDR 2012). Cd can persist in the environment and has a relatively rapid uptake and thus, can easily accumulate in the food chain. Public health concerns stem from the fact that it is a toxic metal even at low concentration levels with associated health issues which affect vital organs of the body including the lungs, kidneys, cardiovascular system, reproductive organs, eyes, and the brain (ATSDR 2012). Unlike the other metals such as Zinc (Zn), which have some nutritional value for normal functional of the human body, $\mathrm{Cd}$ is of no use to the human body and is a known carcinogen. Thus, it is very important to eliminate risks of exposure to $\mathrm{Cd}$ contamination because of these toxic effects even at low concentration levels. According to Food and Agricultural organisation (FAO), the wastewater quality guidelines for agricultural use stipulates that the recommended limit for $C d$ is $0.01 \mathrm{mg} \mathrm{L}^{-1}$ (FAO 1992). Similarly, $0.01 \mathrm{mg} \mathrm{L}^{-1}$ is the recommended limit for Cd based on the US Environmental Protection Agency (EPA) water reuse quality criteria for irrigation purposes (US EPA 2012). In the current study, the concentration of $\mathrm{Cd}$ was far less than the recommended regulatory limits. The derived effluent standard proposed by Newman et al. (2013) is $0.0018 \mathrm{mg} \mathrm{L}^{-1}$ while the miscellaneous irrigation water limits (Long and Short terms) suggested by Rowe and AbdelMagid (1995) are $0.01 \mathrm{mg} \mathrm{L}^{-1}$ and $0.05 \mathrm{mg} \mathrm{L}^{-1}$ respectively. The recorded values for $\mathrm{Cd}$ from the PPS system were all well below these suggested limits. Consequently, the risk of exposure to Cd from the PPS system is very minimal and as such, no threats of possible pollution of farmlands and products, therefore, is of no health concern. 
Table 1: Result of the leachate analysis showing mean concentration of leachates samples from different strata of the PPS

\begin{tabular}{|c|c|c|c|c|c|c|c|c|}
\hline \multirow{2}{*}{\multicolumn{2}{|c|}{ Eluate Analysis }} & \multicolumn{2}{|c|}{$\begin{array}{l}\text { Concentration in } \\
\text { Eluate }\end{array}$} & \multirow{3}{*}{$\begin{array}{c}\text { Derived Effluent } \\
\text { Standard* } \\
\\
\mathrm{mgL}^{-1}\end{array}$} & \multicolumn{2}{|c|}{$\begin{array}{l}\text { Miscellaneous } \\
\text { Irrigation Water } \\
\text { Limits }\end{array}$} & \multirow{3}{*}{$\begin{array}{c}\text { FAO } \\
\text { irrigation } \\
\text { limits } \\
\\
\\
\mathrm{mgL}^{-1}\end{array}$} & \multirow{3}{*}{$\begin{array}{c}\text { US EPA } \\
\text { irrigation } \\
\text { limits } \\
\\
\mathrm{mgL}^{-1}\end{array}$} \\
\hline & & & & & \multirow{2}{*}{\begin{tabular}{|l}
$\begin{array}{l}\text { Long } \\
\text { Term }\end{array}$ \\
$\mathbf{m g L}^{-1}$
\end{tabular}} & \multirow{2}{*}{$\begin{array}{l}\text { Short } \\
\text { Term } \\
\mathbf{m g L}^{-1}\end{array}$} & & \\
\hline Metals & $\begin{array}{l}\text { Profile of } \\
\text { PPS }\end{array}$ & $\mathrm{mgL}^{-1}$ & $\begin{array}{c}\text { Standard } \\
\text { Deviation }^{+}\end{array}$ & & & & & \\
\hline \multirow[t]{5}{*}{ Cadmium as $\mathrm{Cd}$} & $\mathrm{P}$ & $<0.0001$ & --- & \multirow{5}{*}{0.0018} & \multirow{5}{*}{$0.01^{\mathrm{a}}$} & \multirow{5}{*}{$0.05^{a}$} & \multirow{5}{*}{0.01} & \multirow{5}{*}{0.01} \\
\hline & AA & $<0.0001$ & --- & & & & & \\
\hline & $A D$ & $<0.0001$ & --- & & & & & \\
\hline & D & $<0.0001$ & --- & & & & & \\
\hline & G & $<0.0001$ & --- & & & & & \\
\hline \multirow[t]{5}{*}{ Arsenic as As } & $\mathrm{P}$ & $<0.005$ & --- & \multirow{5}{*}{---} & \multirow{5}{*}{$0.1^{\dagger}$} & \multirow{5}{*}{$2.0^{f}$} & \multirow{5}{*}{0.1} & \multirow{5}{*}{0.1} \\
\hline & AA & $<0.005$ & --- & & & & & \\
\hline & $A D$ & $<0.005$ & --- & & & & & \\
\hline & $\mathrm{D}$ & $<0.005$ & --- & & & & & \\
\hline & G & $<0.005$ & --- & & & & & \\
\hline \multirow[t]{5}{*}{ Chromium as $\mathrm{Cr}$} & $\mathrm{P}$ & 0.0058 & 0.0006 & \multirow{5}{*}{0.068} & \multirow{5}{*}{$0.1^{c}$} & \multirow{5}{*}{---} & \multirow{5}{*}{0.1} & \multirow{5}{*}{0.1} \\
\hline & AA & $<0.0025$ & --- & & & & & \\
\hline & $A D$ & $<0.0025$ & --- & & & & & \\
\hline & $\mathrm{D}$ & $<0.0025$ & --- & & & & & \\
\hline & G & $<0.0025$ & --- & & & & & \\
\hline \multirow[t]{2}{*}{ Nickel as $\mathrm{Ni}$} & $P$ & $<0.02$ & --- & \multirow{2}{*}{0.4} & \multirow{2}{*}{$0.5^{b}$} & \multirow{2}{*}{$0.05^{b}$} & \multirow{2}{*}{0.2} & \multirow{2}{*}{0.2} \\
\hline & $A A$ & $<0.02$ & --- & & & & & \\
\hline
\end{tabular}




\begin{tabular}{|c|c|c|c|c|c|c|c|c|}
\hline & $A D$ & $<0.02$ & --- & & & & & \\
\hline & $\mathrm{D}$ & $<0.02$ & --- & & & & & \\
\hline & $\mathrm{G}$ & $<0.02$ & --- & & & & & \\
\hline \multirow[t]{5}{*}{ Copper as $\mathrm{Cu}$} & $P$ & $<0.01$ & --- & \multirow{5}{*}{0.2} & \multirow{5}{*}{$0.2^{\mathrm{a}}$} & \multirow{5}{*}{$5^{a}$} & \multirow{5}{*}{0.2} & \multirow[t]{5}{*}{0.2} \\
\hline & $\mathrm{AA}$ & $<0.01$ & --- & & & & & \\
\hline & $A D$ & $<0.01$ & --- & & & & & \\
\hline & $\mathrm{D}$ & $<0.01$ & --- & & & & & \\
\hline & $\mathrm{G}$ & 0.017 & 0.0005 & & & & & \\
\hline \multirow[t]{5}{*}{ Lead as $\mathrm{Pb}$} & $\mathrm{P}$ & 0.013 & 0.004 & \multirow{5}{*}{0.144} & \multirow{5}{*}{$5^{a}$} & \multirow{5}{*}{$10^{a}$} & \multirow{5}{*}{5} & \multirow{5}{*}{5} \\
\hline & $\mathrm{AA}$ & $<0.01$ & --- & & & & & \\
\hline & $A D$ & $<0.01$ & --- & & & & & \\
\hline & $D$ & 0.011 & 0.008 & & & & & \\
\hline & $\mathrm{G}$ & 0.013 & 0.005 & & & & & \\
\hline \multirow[t]{5}{*}{ Molybdenum as Mo } & $P$ & 0.0049 & 0.0002 & \multirow{5}{*}{---} & \multirow{5}{*}{$0.01^{d}$} & \multirow{5}{*}{$0.05^{d}$} & \multirow{5}{*}{0.01} & \multirow{5}{*}{0.01} \\
\hline & $\mathrm{AA}$ & 0.007 & 0.0003 & & & & & \\
\hline & $A D$ & 0.0068 & 0.0003 & & & & & \\
\hline & $\mathrm{D}$ & 0.007 & 0.0005 & & & & & \\
\hline & $\mathrm{G}$ & 0.0031 & 0.0004 & & & & & \\
\hline \multirow[t]{5}{*}{ Zinc as Zn } & $\mathrm{P}$ & $<0.025$ & --- & \multirow{5}{*}{1} & \multirow{5}{*}{$5^{b}$} & \multirow{5}{*}{---} & \multirow{5}{*}{2} & \multirow{5}{*}{2} \\
\hline & $\mathrm{AA}$ & $<0.025$ & --- & & & & & \\
\hline & $A D$ & $<0.025$ & --- & & & & & \\
\hline & $\mathrm{D}$ & $<0.025$ & -- & & & & & \\
\hline & G & $<0.025$ & --- & & & & & \\
\hline \multirow[t]{3}{*}{ Fluoride as $\mathrm{F}$} & $P$ & 0.18 & 0.033 & \multirow{3}{*}{---} & \multirow{3}{*}{1.0} & \multirow{3}{*}{15.0} & \multirow{3}{*}{1.0} & \multirow{3}{*}{1.0} \\
\hline & $\mathrm{AA}$ & 0.073 & 0.0041 & & & & & \\
\hline & $A D$ & 0.083 & 0.0011 & & & & & \\
\hline
\end{tabular}




\begin{tabular}{|c|c|c|c|c|c|c|c|c|}
\hline & $\mathrm{D}$ & 0.151 & 0.003 & & & & & \\
\hline & G & 0.083 & 0.005 & & & & & \\
\hline \multirow[t]{5}{*}{ Selenium as Se } & $\mathrm{P}$ & $<0.01$ & --- & \multirow{5}{*}{--- } & \multirow{5}{*}{$0.05^{\mathrm{e}}$} & \multirow{5}{*}{$0.05^{\mathrm{e}}$} & \multirow{5}{*}{0.02} & \multirow{5}{*}{0.02} \\
\hline & AA & $<0.01$ & -- & & & & & \\
\hline & $A D$ & $<0.01$ & --- & & & & & \\
\hline & $\mathrm{D}$ & $<0.01$ & --- & & & & & \\
\hline & G & $<0.01$ & --- & & & & & \\
\hline \multirow[t]{5}{*}{ Barium as $\mathrm{Ba}$} & $\mathrm{P}$ & 0.27 & 0.047 & \multirow{5}{*}{--- } & \multirow{5}{*}{--} & \multirow{5}{*}{---} & \multirow{5}{*}{--- } & \multirow{5}{*}{2} \\
\hline & $A A$ & $<0.060$ & --- & & & & & \\
\hline & $A D$ & $<0.060$ & --- & & & & & \\
\hline & $\mathrm{D}$ & $<0.060$ & --- & & & & & \\
\hline & G & $<0.060$ & --- & & & & & \\
\hline \multirow[t]{5}{*}{ Mercury as Hg } & $\mathrm{P}$ & $<0.0005$ & --- & \multirow{5}{*}{---} & \multirow{5}{*}{---} & \multirow{5}{*}{---} & \multirow{5}{*}{---} & \multirow{5}{*}{0.002} \\
\hline & $A A$ & $<0.0005$ & --- & & & & & \\
\hline & $A D$ & $<0.0005$ & -- & & & & & \\
\hline & $\mathrm{D}$ & $<0.0005$ & -- & & & & & \\
\hline & G & $<0.0005$ & --- & & & & & \\
\hline \multirow[t]{5}{*}{ Chloride as $\mathrm{Cl}$} & $\mathrm{P}$ & 16.06 & 1.12 & \multirow{5}{*}{--- } & \multirow{5}{*}{---} & \multirow{5}{*}{---} & \multirow{5}{*}{--- } & \multirow{5}{*}{250} \\
\hline & $A A$ & $<3.7$ & --- & & & & & \\
\hline & $A D$ & $<3.7$ & --- & & & & & \\
\hline & $\mathrm{D}$ & $<3.7$ & --- & & & & & \\
\hline & G & $<3.7$ & --- & & & & & \\
\hline \multirow[t]{4}{*}{ Sulphate as SO4 } & $\mathrm{P}$ & $<4.4$ & --- & \multirow{4}{*}{--- } & \multirow{4}{*}{---} & \multirow{4}{*}{---} & \multirow{4}{*}{---} & \multirow{4}{*}{250} \\
\hline & $A A$ & 23.77 & 3.26 & & & & & \\
\hline & $A D$ & 21.27 & 1.94 & & & & & \\
\hline & $\mathrm{D}$ & 17.55 & 2.64 & & & & & \\
\hline
\end{tabular}


G

*Newman et al. (2013)

**FAO (1992)

***US EPA (2012); Water Research Centre (2014)

a Rowe and AbdelMagid (1995)

${ }^{\text {b Harivandi (1982) }}$

c Nnadi et al. (2014)

d Rizani, and Laze (2017)

e Water Quality Association (2013)

${ }^{f}$ Fipps, G. (1996)

+ Standard Deviation (SD) for values above limits of detection (LOD) 
Other metals such as Arsenic (As), Nickel ( $\mathrm{Ni}$ ) and $\mathrm{Zn}$, all recorded the same concentration levels across the entire profiles with values of $<0.005 \mathrm{mg} \mathrm{L}^{-1},<0.02$ $\mathrm{mg} \mathrm{L}^{-1}$ and $<0.025 \mathrm{mg} \mathrm{L}^{-1}$ respectively.

As, chemically classified as a metalloid (i.e. possesses properties of both a metal and a non-metal), occurs naturally in the soil and is extensively distributed in the Earth's crust. Arsenic is a known human carcinogen which usually combines with other elements such as sulphur, chlorine, oxygen etc. in the natural environment. Other health issues associated with As include decreased production of white and red blood cells, lung/liver/bladder cancer, blood-vessel damage and impaired nerve function etc. (ATSDR 2007).

$\mathrm{Ni}$, the 24th most abundant element, is found primarily combined with sulphur or oxygen as sulphides or oxides and, it has been documented that the earth's core is made up of about $6 \%$ nickel (ATSDR 2005). Some of the harmful health effects associated with exposure to nickel include chronic bronchitis, reduced lung function, and cancer of the lung and nasal sinus (ATSDR 2005).

$\mathrm{Zn}$ is found in the air, water and soil as it is one of the most common elements in the Earth's crust which can exist in pure or combined form. It is also present in several food types because of its nutritional value. $\mathrm{Zn}$ is a vital element which has numerous and very important functions for normal operations of the human body such as, immune system defence for the human body, accelerated healing of wounds, an essential necessity for development and growth (particularly, the brain), breakdown of carbohydrates, cell division and growth etc. (Mbanaso et al. 2019). 
The FAO and US EPA regulatory limits for $\mathrm{As}, \mathrm{Ni}$ and $\mathrm{Zn}$ for agricultural irrigation are $0.1 \mathrm{mg} \mathrm{L}^{-1}, 0.2 \mathrm{mg} \mathrm{L}^{-1}$ and $2 \mathrm{mg} \mathrm{L}^{-1}$ respectively (FAO 1992; US EPA 2012; Water Research Centre (2014). The Long and Short term (Miscellaneous irrigation water) limits are $0.1 \mathrm{mg} \mathrm{L}^{-1}$ and $2.0 \mathrm{mg} \mathrm{L}^{-1}$ for As (Fipps 1996), $0.5 \mathrm{mg} \mathrm{L}^{-1}$ and $0.05 \mathrm{mg} \mathrm{L}^{-1}$ for $\mathrm{Ni}$ (Harivandi 1982) while the Long-term limit for $\mathrm{Zn}$ is $5 \mathrm{mg} \mathrm{L}^{-1}$ (Harivandi 1982). But, current study records of $<0.005 \mathrm{mg} \mathrm{L}^{-1},<0.02 \mathrm{mg} \mathrm{L}^{-1}$ and $<0.025 \mathrm{mg} \mathrm{L}^{-1}$ for As, $\mathrm{Ni}$ and $\mathrm{Zn}$ respectively were all below the regulatory as well as the miscellaneous limits and thus, do not pose any health issues.

Similarly, Selenium (Se) and Mercury $(\mathrm{Hg})$ also recorded the same concentration levels across the entire profiles with values of $<0.01 \mathrm{mg} \mathrm{L}^{-1}$ and $<0.0005 \mathrm{mg} \mathrm{L}^{-1}$ respectively. These values are also below the regulatory limits of $0.02 \mathrm{mg} \mathrm{L}^{-1}$ and $0.002 \mathrm{mg} \mathrm{L}^{-1}$ respectively and hence, are of no environmental or health concern.

Copper $(\mathrm{Cu})$ and Lead $(\mathrm{Pb})$ recorded maximum concentrations of $0.017 \mathrm{mg} \mathrm{L}^{-1}$ from the pavement blocks and $0.013 \mathrm{mg} \mathrm{L}^{-1}$ from the pavement blocks/geotextile layer respectively. Again, these values are below the regulatory limits of $0.2 \mathrm{mg} \mathrm{L}^{-1}$ and 5 $\mathrm{mg} \mathrm{L}^{-1}$ respectively and will therefore, not pose any health risks.

These findings indicate that recycling of aggregates from demolition wastes arising from end of life PPS would not be limited by the potential leaching of toxic metals. They may, therefore, be deployed for other re-use applications including re-use within another PPS.

\subsection{Analysis of Leachates}


The results from the analysis of leachates which were done on samples from the entire PPS profile are as shown in Table 2. The data shows that $\mathrm{As}, \mathrm{Ni}$ and $\mathrm{Se}$ recorded the same concentration levels across the entire profiles with values of $<$ $0.05 \mathrm{mg} \mathrm{kg}^{-1},<0.2 \mathrm{mg} \mathrm{kg}^{-1}$ and $<0.1 \mathrm{mg} \mathrm{kg}^{-1}$ respectively. Samples from the pavement blocks recorded the highest concentrations of Barium (Ba), $\mathrm{Zn}$ and Chloride (Cl) with values of $3.3 \mathrm{mg} \mathrm{kg}^{-1}, 0.179 \mathrm{mg} \mathrm{kg}^{-1}$ and $223 \mathrm{mg} \mathrm{kg}^{-1}$ respectively while, those of the Geotextile fibre recorded the highest concentrations of Copper (Cu) and $\mathrm{Hg}$ with $0.17 \mathrm{mg} \mathrm{kg}^{-1}$ and $0.008 \mathrm{mg} \mathrm{kg}^{-1}$ respectively.

Table 2: The EU Landfill Waste Acceptance limit values and sampling results obtained from eluate analysis of the PPS constituent parts for waste-derived aggregates utilisation

\begin{tabular}{|c|c|c|c|c|c|c|}
\hline \multirow{2}{*}{$\begin{array}{l}\text { Eluate Analysis } \\
\text { Mass of Raw Test Portion (MW) kg } \\
\end{array}$} & \multicolumn{5}{|c|}{ Amount Leached } & \multirow{5}{*}{$\begin{array}{c}E U \\
\frac{\text { Landfill Waste Acceptance }}{\text { Criteria }} \\
\begin{array}{c}\text { BS EN 12457-3 Limit Values } \\
(\mathrm{mg} / \mathrm{Kg})\end{array}\end{array}$} \\
\hline & 0.179 & 0.175 & 0.175 & 0.175 & 0.091 & \\
\hline Mass of Dried Test Portion (MD) kg & 0.175 & 0.175 & 0.175 & 0.175 & 0.09 & \\
\hline Moisture Content Ratio (MC) \% & 2.83 & 0.2 & 0.2 & 0.3 & 1.32 & \\
\hline \multirow[t]{2}{*}{ Dry Matter Content Ratio (DR) \% } & 97.24 & 99.8 & 99.8 & 99.7 & 98.7 & \\
\hline & $\begin{array}{l}P \\
(\mathrm{mg} / \mathrm{Kg})\end{array}$ & $\begin{array}{l}\text { AA } \\
(\mathrm{mg} / \mathrm{Kg})\end{array}$ & $\begin{array}{l}\text { AD } \\
(\mathrm{mg} / \mathrm{Kg})\end{array}$ & $\begin{array}{l}D \\
(\mathrm{mg} / \mathrm{Kg})\end{array}$ & $\begin{array}{l}\text { G } \\
(\mathrm{mg} / \mathrm{Kg})\end{array}$ & $\begin{array}{c}\text { Inert } \\
(\mathrm{mg} / \mathrm{Kg})\end{array}$ \\
\hline Arsenic (As) & $<0.0500$ & $<0.0500$ & $<0.0500$ & $<0.0500$ & $<0.0500$ & 0.5 \\
\hline Barium (Ba) & 3.30000 & $<0.6000$ & $<0.6000$ & $<0.6000$ & $<0.6000$ & 20 \\
\hline Cadmium (Cd) & $<0.0010$ & 0.00014 & 0.00072 & 0.00061 & $<0.0010$ & 0.04 \\
\hline Chromium (Cr) & 0.05700 & $<0.0250$ & $<0.0250$ & $<0.0250$ & $<0.0250$ & 0.5 \\
\hline Copper (Cu) & $<0.1000$ & $<0.1000$ & 0.04500 & 0.05200 & 0.17000 & 2 \\
\hline Mercury (Hg) & 0.00340 & 0.00236 & 0.00450 & $<0.0050$ & 0.00800 & 0.01 \\
\hline Molybdenum (Mo) & 0.05100 & 0.12000 & 0.14300 & 0.08500 & 0.03100 & 0.5 \\
\hline Nickel (Ni) & $<0.2000$ & $<0.2000$ & $<0.2000$ & $<0.2000$ & $<0.2000$ & 0.4 \\
\hline Lead $(\mathrm{Pb})$ & 0.12500 & 0.09000 & 0.07300 & 0.12000 & 0.13000 & 0.5 \\
\hline Selenium (Se) & $<0.1000$ & $<0.1000$ & $<0.1000$ & $<0.1000$ & $<0.1000$ & 0.1 \\
\hline Zinc (Zn) & 0.17900 & $<0.2500$ & $<0.2500$ & 0.14300 & $<0.2500$ & 4 \\
\hline Chloride $(\mathrm{Cl})$ & 223.000 & 9.17000 & 27.9000 & 21.6500 & $<37.000$ & 800 \\
\hline Fluoride (F) & 1.60000 & 1.03000 & 1.37000 & 1.50000 & 0.93000 & 10 \\
\hline Sulphate (SO4) & 50.660 & 586 & 893 & 605 & 190 & 1000 \\
\hline
\end{tabular}

The European Union (EU) Waste Framework Directive (WFD) 2008/98/EC includes the possibility to reclassify wastes based on end-of-waste (EoW) criteria under which 
specified fractions of waste shall cease to be waste (EU 2014). In assessing the suitability of a waste material for reclassification, these criteria have to be met. According to EU (2014), if these criteria are fulfilled, the material will no longer be classified as a waste, but it will instead become a product subject to free trade and use. When a waste material has undergone a recovery or treatment process, it may be assessed to determine whether it has a market value and thus, may be reused or recycled. Such a material will have to fulfil certain technical and legislative requirements for the specific purpose applicable to the products. The assessment will also include determination of potential adverse environmental or human health impacts.

The generation or creation of solid waste in both developed and developing countries is a common occurrence (Tam et al. 2018). When these solid wastes are generated, they are typically dumped in landfill sites capable of causing air, water or soil contamination. As a result of tougher environmental legislations and high landfilling costs occasioned by depleting of landfilling resources, there is a worldwide re-evaluation of waste management approaches intended to enhance the optimization of the re-use and recycling of Construction and Demolition (C\&D) waste (Mbanaso et al. 2019). According to a Technical Report by the Joint Research Centre of the European Commission (JRC91036), leaching tests should be used to assess conformity with EoW criteria (EU 2014). This Technical report (JRC91036) specified that instead of using total composition analysis (content), leaching tests should be used to appraise potential release of substances from aggregates since the leaching properties of an aggregate are directly related to risk of such impacts. Accordingly, some EU Member States have adopted the EU leaching Waste Acceptance Criteria 
(WAC) for landfilling of inert waste as the basis of assessment of suitability of wastederived aggregates for reuse purposes. Those relying fully or partly on the EU Landfill Directive (LFD) WAC for inert waste include Austria, Czech Republic, and Finland (EU 2014).

From the forgoing, it could be seen from Table 2 that all results are below the EU LFD WAC for inert waste limits, indicating that the waste-derived aggregates can be reused and recycled.

\section{CONCLUSION}

Measured concentrations of all metals were below the appropriate risk-based regulatory threshold values for irrigation purposes as specified by FAO and USEPA. This suggests that, for metals, there is no potential pollution of water resources such as groundwater, surface waters, rivers or aquifers. It also indicates that there are no pollution threats to agricultural farmlands and produce with respect the contaminants studied. However, as previously mentioned, microbiological issues may be a useful progression to this study.

Furthermore, the EoW assessment showed that the eluate amount of the 14 metals leached from the PPS system were all below the EU LFD WAC for inert waste and therefore, may be reused without any environmental concerns. This indicates that the dismantled materials can be reused as recycled aggregates for other civil construction purposes. This has potential to increase recycling of aggregates from construction and demolition wastes and minimize dependence on virgin aggregates 
and hence, reduction on exploitation of natural resources and improvement of sustainability credentials of the PPS system.

\section{ACKNOWLEDGEMENTS}

The sponsorship for this study was provided by the Centre for Agroecology, Water and Resilience (CAWR) while, Coventry University provided the funding. The authors are grateful and wish to acknowledge their support.

\section{$\underline{\text { References }}$}

Agency for Toxic Substances and Disease Registry (ATSDR) (2005) Toxicological profile for Nickel. Atlanta, GA: U.S. Department of Health and Human Services, Public Health Service (online) available from https://www.atsdr.cdc.gov/PHS/PHS.asp?id=243\&tid=44 (05/01/2019).

Agency for Toxic Substances and Disease Registry (ATSDR) (2007) Toxicological profile for Arsenic. Atlanta, GA: U.S. Department of Health and Human Services, Public Health Service (online) available from https://www.atsdr.cdc.gov/PHS/PHS.asp?id=18\&tid=3 (05/01/2019).

Agency for Toxic Substances and Disease Registry (ATSDR) (2012) Toxicological Profile for Cadmium. Atlanta, GA: U.S. Department of Health and Human Services, Public Health Service (online) available from https://www.atsdr.cdc.gov/phs/phs.asp?id=46\&tid=15 (05/01/2019)

ATSDR (1995). Toxicological profile for Polycyclic Aromatic Hydrocarbons (PAHs). Atlanta, GA: U.S. Department of Health and Human Services, Public Health Service (online) available from https://www.atsdr.cdc.gov/toxprofiles/tp.asp?id=122\&tid=25 (20/04/2018)

ATSDR (2017) ATSDR's Substance Priority List (online) available from https://www.atsdr.cdc.gov/spl/index.html (12/06/2018) 
Baladès J.D., Bourgogne P., Madiec H. (1992). Evaluation des flux de pollution transitant dans un type de solution compensatoire. Conf. Novatech, Lyon, pp. 66-75.

Bond, P. C. (1999) Mineral Oil Biodegradation within Permeable Pavements: LongTerm Observations. Unpublished PhD thesis, Coventry University, Coventry, UK.

Boström, C.E., Gerde, P., Hanberg, A., Jernstrom, B., Johansson, C., Kyrklund, T., Rannug, A., Tornqvist, M., Victorin, K and Westerholm, R. (2002) Cancer risk assessments, indicators, and guidelines for polycyclic aromatic hydrocarbons in the ambient air Environ. Health Perspect., 110 (Suppl. 3) (2002), pp. 451-488

Braswell, A.S., Anderson, A.R. and Hunt III, W.F. (2018) Hydrologic and Water Quality Evaluation of a Permeable Pavement and Biofiltration Device in Series. Water 2018, 10, 33; doi:10.3390/w10010033

CASQA (2003) Stormwater Best Management Practice Handbook: New Development and Redevelopment (online) available from https://www.casqa.org/sites/default/files/BMPHandbooks/BMP NewDevRedev_Co mplete.pdf $(20 / 04 / 2018)$

Castro, D., Slezakova, K., Delerue-Matos, C., Alvim-Ferraz, M.C., Morais, S., and Pereira, M.C. (2011) Polycyclic aromatic hydrocarbons in gas and particulate phases of indoor environments influenced by tobacco smoke: levels, phase distributions and health risk. Atmos. Environ., 45 (2011), pp. 1799-1808

CIRIA (2015) The SuDS Manual (C753) (online) available from https://www.ciria.org/Memberships/The SuDs Manual C753 Chapters.aspx $(20 / 04 / 2018)$

Das, C.K and Saikia, M.D. (2018) Water Harvesting using Permeable Pavement for Guwahati city. Engineering and Technology Vol. 7, Issue 5

Department for Communities and Local Government (2012) Re-imagining urban spaces to help revitalise our high streets (online) available from https://assets.publishing.service.gov.uk/government/uploads/system/uploads/attac hment data/file/5987/2185491.pdf (22/06/2018)

Dierkes, C., Kuhlmann, L., Kandasamy, J. and Angelis, G. (2002) Pollution retention capability and maintenance of permeable pavements. Proc. 9th International Conference on Urban Drainage, Global Solutions for Urban Drainage (2002), pp. 8-13

Dierkes, C., Kuhlmann, L., Kandasamy, J. and Angelis, G. (2002) Pollution Retention Capability and Maintenance of Permeable Pavements. Proc. 9th International Conference on Urban Drainage (9ICUD) September 8-13, 2002, Lloyd Center Doubletree Hotel, Portland, Oregon, United States 
Environment Agency (2015) Delivering Benefits through evidence: Cost estimation for SUDS - summary of evidence http://evidence.environmentagency.gov.uk/FCERM/Libraries/FCERM Project Documents/SC080039 cost SUDS.S flb.ashx (02/02/2018)

EU (2014) Study on methodological aspects regarding limit values for pollutants in aggregates in the context of the possible development of end-of-waste criteria under the EU Waste Framework Directive; Joint Research Centre Institute for Prospective Technological Studies (online) available from http://susproc.jrc.ec.europa.eu/activities/waste/documents/Aggregates\%20leaching \%20Main.pdf (12/05/2018)

FAO (1992) Wastewater treatment and use in agriculture; FAO irrigation and drainage paper 47 (online) available from http://www.fao.org/docrep/T0551E/T0551E00.htm (02/05/2018)

FAO (2015) 2050: A third more mouths to feed (online). Available from http://www.fao.org/news/story/en/item/35571/icode/ [10/12/2015]

Fipps, G. (1996) Irrigation Water Quality Standards and Salinity Management Strategies. Texas Agricultural Extension Service, Texas A\&M University System (online) available from https://aglifesciences.tamu.edu/baen/wp-content/uploads/sites/24/2017/01/B-1667.Irrigation-Water-Quality-Standards-and-Salinity-Management-Strategies.pdf (21/10/2018)

Greater London Authority (2016) London Sustainable Drainage Action Plan (online) available from https://www.london.gov.uk/sites/default/files/Isdap december_2016.pdf (06/01/2019)

Harivandi, M.A. (1982) 'The Use of Effluent Water for Turfgrass Irrigation.'. Cooperative Extension: California Rurfgrass Culture 32. Nos. 3 \& 4. (online) available from https://agops.ucr. edu/turf/publications/ctc/ctc32_34.pdf (12.09.14.)

Hogland, W., Niemczynowicz J. and Wahlman T. (1987) The unit superstructure during the construction period. Science of the Total Environment, 59, pp. 411-424.

Imbe M., Okui H., Hashimoto C. and Musiake K., (2002) Monitoring and analysis of implemented infiltration system over past 20 years. Proc. 9th Int. Conf. on Urban Drainage, Global Solutions for Urban Drainage, Eds. E W Strecker and W C Huber, Portland, Oregon, USA. ISBN 0784406448 (40644-009-003.pdf).

Imran, H.M., Akib, S. and Karim, M.R. (2013) Permeable pavement and stormwater management systems: a review, Environmental Technology, 34:18, 2649-2656, DOI: 10.1080/09593330.2013.782573

INTERPAVE (2006) CONCRETE BLOCK PERMEABLE PAVEMENTS (online) available from http://www.paving.org.uk/commercial/documents/faqv1.pdf (20/04/2018) 
INTERPAVE (2008) Understanding permeable paving: Guidance for Designers, Developers, Planners and Local Authorities (online) available from https://assets.marshalls.co.uk/dam-svc/assetstore/interpave--understandingpermeable-paving-6174.pdf (20/04/2018)

IPCC (2013) Climate Change 2013: The Physical Science Basis [online]. Available from http://ipcc.ch/ [28/09/2013].

Jaishankar, M., Tseten, T., Anbalagan, N., Mathew, B.B. and Beeregowda, K.N. (2014) Toxicity, mechanism and health effects of some heavy metals. Interdiscip Toxicol. 7(2): 60-72. doi: 10.2478/intox-2014-0009

Keith, L.H. (2015) The Source of U.S. EPA's Sixteen PAH Priority Pollutants. Polycyclic Aromatic Compounds. 0 (2-4): 1-14. doi:10.1080/10406638.2014.892886 (online) available from https://www.tandfonline.com/doi/full/10.1080/10406638.2014.892886 (20/04/2018)

Kelly, D.A. (2016) Impact of paved front gardens on current and future urban flooding. Journal of Flood Risk Management 11 (S1) S434-S443

Legret, M., Colandini, V. and Marc, C.L. (1996) Effects of a porous pavement with reservoir structure on the quality of runoff water and soil. Science of the Total Environment 189/190 (1996) $335-340$

LID Centre (2007) Introduction to LID (online). Available from http://www.lidstormwater.net/background.htm [11/12/2015].

Liu, Y., Li, T. and Peng, H. (2018) A new structure of permeable pavement for mitigating urban heat island. Sci Total Environ. 1;634: 1119-1125. doi: 10.1016/j.scitotenv.2018.04.041.

London Assembly (2005) Crazy Paving: the environmental importance of London's from gardens. London: Greater London Authority online]. Available from http://legacy.london.gov.uk/assembly/reports/environment/frontgardens.pdf [24/11/2010]

Mbanaso, F.U., Charlesworth, S.M., Coupe, S.J., Newman, A.P. and Nnadi, E.O. (2019) Reuse of materials from a Sustainable Drainage System device: Health, Safety and Environment assessment for an end-of-life Pervious Pavement Structure. Science of The Total Environment 650, Part 2, Pages 1759-1770

Mbanaso, F.U., Coupe S.J, Charlesworth S.M, Nnadi E.O. (2013) 'Laboratory-based experiments to investigate the impact of glyphosate-containing herbicide on 
pollution attenuation and biodegradation in a model pervious paving system'. Chemosphere 90, $737-746$.

Newman, A., Puehmeier, T., Shuttleworth, A. and Pratt, C.J. (2014) Performance of an enhanced pervious pavement system loaded with large volumes of hydrocarbons. Water Science and Technology, 70(5), 835-842.

Newman, A.P., Shuttleworth, A., Nnadi, E.O., Mbanaso, F.U., Ladislao B.A., Douglas Aitken, D. and Puehmeier, T. (2015a) Do Pervious Pavements Really Need Pervious Surfaces? The Concept of the Macro-pervious Pavement as a SuDS Device (online) available from: https://www.researchgate.net/publication/279749643_Do_Pervious_Pavements_Really_Need_Pervi ous_Surfaces_The_Concept_of_the_Macro-pervious_Pavement_as_a_SuDS_Device $(16 / 11 / 2018)$

Newman A.P., Nnadi E.O., Mbanaso F.U., Shutleworth, A. , Aitken, D., AntizarLadislao, B. \& Theophilus, S.C. (2015b) Potential of Pervious and MacroPervious Pavements as Harvesting Systems for Irrigation of Adjacent Lawns and Flower Beds (online) available from: https://www.researchgate.net/publication/296307684_Potential_of_Pervious_and_MacroPervious_Pavements_as_Harvesting_Systems_for_Irrigation_of_Adjacent_Lawns_and_Flower_Beds (12/10/2018).

Newman, A.P., Aitken, D. and Antizar-Ladislao, B. (2013) Stormwater quality performance of a macro-pervious pavement car park installation equipped with channel drain based oil and silt retention devices. Water Research 47 (20) 73277336, http://dx.doi.org/10.1016/i.watres.2013.05.061

Newman, A.P., Nnadi, E.O., Duckers, L.J. and A.J. Cobley, A.J. (2011) Further developments in self-fertilising geotextiles for use in pervious pavements. Water Sci. Technol., 64 (2011), pp. 1333-1339

Nnadi, E.O. (2009). An evaluation of modified pervious pavements for water harvesting for irrigation purposes. Unpublished PhD Thesis. Coventry: Coventry University.

Nnadi, E.O., Newman, A.P., Coupe, S.J. and Mbanaso, F.U., (2014) Stormwater Harvesting for Irrigation Purposes: An Investigation of Chemical Quality of Water Recycled In Pervious Pavement System. J. Environ Mgt., 147: 246-256.

Nnadi, E.O., Newman, A.P., Coupe, S.J., Mbanaso, F.U. (2015) Stormwater harvesting for irrigation purposes: An investigation of chemical quality of water recycled in pervious pavement system. Journal of Environmental Management 147 (2015):246256. DOI: 10.1016/j.jenvman.2014.08.020 
Permavoid System Technical Manual (2016). Planning, design, specification and installation guide (online) available from https://www.polypipe.com/sites/default/files/WEB_PCL_14_234_Permavoid_Technical_Manual_2015_4.pdf (12/11/2018)

Perry, T. and Nawaz, R. (2008) An Investigation into the Extent and Impacts of Hard Surfacing of Domestic Gardens in an Area of Leeds, United Kingdom. Landscape and Urban Planning 86(1):1-13. DOI: 10.1016/j.landurbplan.2007.12.004

Pratt, C. J. (2004) SUSTAINABLE DRAINAGE: A Review of Published Material on the Performance of Various SUDS Components prepared for the UK Environment Agency. Coventry University, UK (online) available from https://www.susdrain.org/files/resources/evidence/suds lit review 04.pdf (20/04/2018).

RAC Foundation (2012) Spaced Out: Perspectives on parking policy (online) available from https://www.racfoundation.org/assets/rac foundation/content/downloadables/spaced out -bates leibling-jul12.pdf (16/04/2018)

Ramesh, A.; Archibong, A.; Hood, D.B.; Guo, Z.; Loganathan, B. G. (2011). "Global environmental distribution and human health effects of polycyclic aromatic hydrocarbons". Global Contamination Trends of Persistent Organic Chemicals. Boca Raton, FL: CRC Press. pp. 97-126.

RHS (2015) Three times as many front gardens completely paved as a decade ago, says Royal Horticultural Society (online) available from https://www.independent.co.uk/news/uk/home-news/three-times-as-many-front-gardenscompletely-paved-as-a-decade-ago-says-royal-horticultural-society-10256660.html (06/01/2019)

Rizani, S. and Laze, P. (2017) Trace Elements Concentration in Surface Water Used for Irrigation in Kosovo. Environment and Ecology Research 5(7): 500-509, DOI: 10.13189/eer.2017.050706

Rowe, D.R., Abel-Magid, I.M., (1995) Handbook of Wastewater Reclamation and Reuse. CRC Press Inc., New York

Sañudo-Fontaneda, L.A, Andrés-Valeri, V.C., Coupe, S.J., Hunt, W.F., Charlesworth, S.M., Coz-Díaz, J.J., Castro-Fresno, D., Newman, A.P., Alvarez-Rabanal, F.P., Sampedro-García, J.L., Lashford, C., Alonso-Martinez, M. and Juli-Gándara, L. (2017) Green infrastructure and ground source heat pump as a combined technique for flood management and energy saving in the cities of the future. Proc. 14th International Conference on Urban Drainage (ICUD), 10-15 September 2017, Prague, Czech Republic. DOI: 10.13140/RG.2.2.36587.23840

Sañudo-Fontaneda, L.A., Andres-Valeri, V, C., Costales-Campa, C., Cabezon-Jimenez, I. and Cadenas-Fernandez, F. (2018) The Long-Term Hydrological Performance of 
Permeable Pavement Systems in Northern Spain: An Approach to the "End-of-Life" Concept. Water 2018, 10(4), 497; doi:10.3390/w10040497

Schlüter W. \& Jefferies C. (2001) Monitoring the outflow from a Porous Car Park Proc. First National Conference on Sustainable Drainage Systems, Coventry June 2001.

Shackel B. (2010). The Design, Construction and Evaluation of Permeable Pavements in Australia. Proc. 24th ARRB Conference - Building on 50 years of road and transport research, Melbourne, Australia.

Simko, P. (2002) Determination of polycyclic aromatic hydrocarbons in smoked meat products and smoke flavouring food additives. J. Chromatogr. B, 770 (1-2) (2002), pp. 3-18

Smith, D. (2019) Permeable Pavement Comparisons, Interlocking Concrete Pavement Institute (online) available from http://www.masonrydesignmagazine.com/permeable-pavement-comparisons/ (10/07/2019)

Sounthararajah, D.P., Loganathan, P., Kandasamy, J. and Vigneswaran, S. (2017) Removing heavy metals using permeable pavement system with a titanate nanofibrous adsorbent column as a post treatment. Chemosphere 168, Pages 467-473

Tam, V.W.Y, Soomro, M. and Evangelista, A.C.J. (2018) A review of recycled aggregate in concrete applications (2000 - 2017). Construction and Building Materials 172 (2018) $272-292$

UN (2018) Sustainable cities - gateways for people on the move (online) available from https://www.un.org/development/desa/en/news/population/cpd51sustainable-cities.html (16/04/2018)

US EPA (2012) 2012 Guidelines for Water Reuse; EPA/600/R-12/618 (online) available from https://nepis.epa.gov/Adobe/PDF/P100FS7K.pdf (21/04/2018)

USGS (2018) Evaluating the potential benefits of permeable pavement on the quantity and quality of stormwater runoff (online) available from https://www.usgs.gov/science/evaluating-potential-benefits-permeable-pavementquantity-and-quality-stormwater-runoff?qt-science center objects=0\#qtscience center objects (06/01/2019)

Water Quality Association (2013) Technical Fact Sheet - Selenium (online) available from https://www.wqa.org/Portals/0/Technical/Technical\%20Fact\%20Sheets/2015 Selenium.pdf $(06 / 11 / 2018)$

Water Research Centre (2014) Barium In Drinking Water Water Testing Kits (online) available from https://www.water-research.net/index.php/barium (16/06/2018) 
Wild, T.C., Jefferies, C., and D'Arcy, B.J. (2002) SUDS in Scotland - the Scottish SUDS database Report No SR (02)09 Scotland and Northern Ireland Forum for Environmental Research, Edinburgh.

Wright, G.B., Arthur, S., Bowles, G., Bastien, N. and Unwin, D. (2011) Urban creep in Scotland: stakeholder perceptions, quantification and cost implications of permeable solutions. Water and Environment Journal 25(4):513 - 521

Zhou, Z., Qu, L. and Zou, T. (2015) Quantitative Analysis of Urban Pluvial Flood Alleviation by Open Surface Water Systems in New Towns: Comparing Almere and Tianjin Eco-City. Sustainability 7, 13378-13398; doi:10.3390/su71013378 